\title{
Shewanella pealeana sp. nov., a member of the microbial community associated with the accessory nidamental gland of the squid Loligo pealei
}

\author{
Michael R. Leonardo, ${ }^{1 \dagger}$ Duane P. Moser, ${ }^{1} \ddagger$ Elena Barbieri, ${ }^{2}$ \\ Christine A. Brantner, ${ }^{3}$ Barbara J. MacGregor, ${ }^{4}$ Bruce J. Paster, ${ }^{5}$ \\ Erko Stackebrandt ${ }^{6}$ and Kenneth $\mathrm{H}$. Nealson ${ }^{7}$
}

\author{
Author for correspondence: Michael R. Leonardo. Tel: + 1205348 5191. Fax: + 12053481403 \\ e-mail: mleonard ( biology.as.ua.edu
}

\footnotetext{
1 Center for Great Lakes Studies, University of Wisconsin-Milwaukee, Milwaukee, WI 53204, USA

2 Istituto di Scienze Tossicogiche Ingienstiche e Ambientali, University of Urbino, 61029 Urbino, Italy

3 Department of Biological Sciences, University of Wisconsin-Milwaukee, Milwaukee, WI 53211, USA

4 Department of Civil Engineering, Northwestern University, Evanston, IL 60208, USA

5 Department of Molecular Genetics, Forsyth Institute, Boston, MA 02115, USA

6 Deutsche Sammlung von Mikroorganismen und Zellkulturen $\mathrm{GmbH}$, Mascheroder Weg 1b, D-38124 Braunschweig, Germany

7 Jet Propulsion Laboratories, California Polytechnic Institute, Pasadena, CA 91109, USA
}

\begin{abstract}
A new, mesophillic, facultatively anaerobic, psychrotolerant bacterium, strain ANG-SQ1 ${ }^{\top}$ ( $T$ = type strain), was isolated from a microbial community colonizing the accessory nidamental gland of the squid Loligo pealei. It was selected from the community on the basis of its ability to reduce elemental sulfur. The cells are motile, Gram-negative rods (2.0-3.0 $\mu \mathrm{m}$ long, 0.4-0.6 $\mu \mathrm{m}$ wide). ANG-SQ1 ${ }^{\top}$ grows optimally over the temperature range of $25-30{ }^{\circ} \mathrm{C}$ and a pH range of 6.5-7.5 ${ }^{\circ} \mathrm{C}$ in media containing $0.5 \mathrm{M} \mathrm{NaCl}$. $16 \mathrm{~S}$ rRNA sequence analysis revealed that this organism belongs to the $y-3$ subclass of the Proteobacteria. The closest relative of ANG-SQ ${ }^{\top}$ is Shewanella gelidimarina, with a 16S rRNA sequence similarity of $97.0 \%$. Growth occurs with glucose, lactate, acetate, pyruvate, glutamate, citrate, succinate, Casamino acids, yeast extract or peptone as sole energy source under aerobic conditions. The isolate grows anaerobically by the reduction of iron, manganese, nitrate, fumarate, trimethylamine- $\mathrm{N}$-oxide, thiosulfate or elemental sulfur as terminal electron acceptor with lactate. Growth of ANG-SQ1' was enhanced by the addition of choline chloride to growth media lacking Casamino acids. The addition of leucine or valine also enhanced growth in minimal growth media supplemented with choline. The results of both phenotypic and genetic characterization indicate that ANG-SQ1' is a Shewanella species. Thus it is proposed that this new isolate be assigned to the genus Shewanella and that it should be named Shewanella pealeana sp. nov., in recognition of its association with $L$. pealei.
\end{abstract}

Keywords: Shewanella pealeana, Loligo pealei, sulfur reducer, choline

\section{INTRODUCTION}

Shewanella species have been isolated from a wide range of environments. For example, Shewanella putrefaciens has been found in a variety of aquatic environments (freshwater, D. P. Moser, M. R. Leonardo, K. Venkateswaran \& K. H. Nealson, un- published results; and marine, Nealson et al., 1991); sediments (Myers \& Nealson, 1988) and in oilfield fluids (Semple \& Westlake, 1987). S. putrefaciens and other Shewanella species have been implicated as causative agents in marine-animal disease (Aguire et al., 1994) and in the spoilage of proteinaceous foods (Curtiss, 1931; Parker \& Levin, 1983; Stenström \&

†Present address: Department of Biological Sciences, The University of Alabama, Box 870206 Tuscaloosa, AL 35487-0206, USA

$\ddagger$ Present address: Department of Geosciences, Princeton University, Princeton, NJ 08544, USA.

Abbreviations: ANG, accessory nidamental gland; CAA, Casamino acids; EPS, exopolysaccharide; FAME, fatty acid methyl ester; PTA, phosphotungstic acid; RDP, Ribosomal Database Project; TEM, transmission electron microscopy; TMAO, trimethylamine- $\mathrm{N}$-oxide. The GenBank accession number for the 165 rRNA gene fragment (1492 bp) of strain ANG-SQ1 ${ }^{\top}$ is AF011335. 
Molin, 1990). The prevalence of Shewanella species in these niches may be a result of their capacity to exploit a wide variety of compounds for both aerobic and anaerobic growth. S. putrefaciens is capable of the dissimilatory reduction of a variety of electron acceptors, including iron, manganese, nitrate, nitrite, thiosulfate, DMSO, trimethylamine $N$-oxide (TMAO), glycine, fumarate and elemental sulfur (Moser \& Nealson, 1996a; Myers \& Nealson, 1988, 1990). Molecular hydrogen (Lovley et al., 1989), as well as a diverse range of simple carbon compounds, can be utilized as electron donors for these reactions (Nealson et al., 1991). Because of their metabolic versatility and wide distribution in a variety of aquatic habitats (Nealson \& Myers, 1992), Shewanella-like organisms are thought to play a significant role in the cycling of organic carbon and other bionutrients (Nealson, 1997).

The accessory nidamental gland (ANG), an organ in the reproductive system of female squids (orders Sepioidea and Teuthoidea), has been shown to harbour a dense microbial community (Bloodgood, 1977; Getzel, 1934; Lum-Kong \& Hastings, 1992). When the squid reaches sexual maturity, the ANG turns from almost colourless to an orange/red colour, possibly because of pigments produced by some members of the squid's associated microbiota (Bloodgood, 1977; Van den Branden et al., 1979). Early efforts led to the isolation of a small number of bacterial types that were superficially characterized by their morphology and pigmentation, but no attempt was made to identify these organisms or describe their biochemical characteristics. These initial studies, some of which were performed decades apart, yielded similar bacterial types (Bloodgood, 1977; Getzel, 1934; Lum-Kong \& Hastings, 1992), suggesting a specific association between the ANG and the microbial community. The role of the ANG and its microbiota in the reproductive cycle of the squid is unclear. However, it is hypothesized that the microbiota could protect the eggs from predation once laid (Barbieri et al., 1997).

During the 1996 Microbial Diversity Course at the Marine Biological Laboratory (MBL, Woods Hole, MA, USA), the ANG microbial community was characterized using both culture-based and molecular approaches. A more detailed characterization of the cultivable ANG microbial community is reported elsewhere (Barbieri et al., 1999). Course participants screened the ANG microbial population for the presence of elemental sulfur-reducing bacteria, using an adaptation of a previously described cultivationbased approach (Moser \& Nealson, 1996a). All of the sulfur-reducing, facultative anaerobes obtained by this method appeared to be represented by a single colony and cell-morphology type. In this study, the morphological, phenotypic and phylogenetic characteristics of a representative ANG sulfur reducer are described. Initial work performed during the Microbial Diversity Course, and supported by our own analyses, suggests that these sulfur reducers represent a novel
Shewanella species. We propose the name Shewanella pealeana sp. nov., because of its association with the ANG of Loligo pealei, and designate ANG-SQ $1^{\mathrm{T}}$ the type strain.

\section{METHODS}

Bacterial strain isolation and growth conditions. For the isolation of strain ANG-SQ1 ${ }^{\mathrm{T}}$ ( $\mathrm{T}=$ type strain), ANGs were dissected from live, mature, female squids $(n=6)$ under aseptic conditions, washed in filtered, autoclaved seawater and the fluids collected from different internal areas of the gland using sterile capillary pipettes. This fluid was streaked for isolation on to Luria-Bertani (LB) agar plates $(50 \mu \mathrm{l}$ per plate) supplemented with $30 \mathrm{mM}$ sodium lactate and $40 \mathrm{mM}$ elemental sulfur prepared as described by Moser $\&$ Nealson (1996a). The plates were incubated for $48 \mathrm{~h}$ at $25^{\circ} \mathrm{C}$ to obtain a collection of cultivable microbes. The plates were then moved to a Coy anaerobic chamber (Coy Instruments), maintained with a $2 \% \mathrm{H}_{2}$ atmosphere, to screen for that subset of the isolates able to reduce elemental sulfur (Moser \& Nealson, 1996a, b). Colonies with cleared zones beneath and around them were scored as positive. Six of the numerous sulfur-reducing colonies were selected at random for further study.

The sulfur-reducing ANG strains were maintained on Marine Broth Agar (Difco Laboratories). To determine the $\mathrm{NaCl}$ concentration that was optimal for growth of these strains, our standard Shewanella medium (M1; Myers \& Nealson, 1988), supplemented with $20 \mathrm{mM}$ sodium lactate and $0.001 \%$ Casamino acids (CAA; Difco Laboratories) was used. $\mathrm{NaCl}$ was added to final concentrations of $0 \cdot 0$, $0 \cdot 125,0 \cdot 25,0 \cdot 5,0 \cdot 75,1 \cdot 0,1 \cdot 25,1.5$ and $1.75 \mathrm{M}$. Experiments were performed in $125 \mathrm{ml}$ Erlenmeyer flasks with vigorous agitation (150 r.p.m.). A final concentration of $0.5 \mathrm{M} \mathrm{NaCl}$ proved optimal; M1 supplemented at this concentration $(\mathrm{M} 1 \mathrm{~N})$ was subsequently employed as our routine growth medium. Controlled temperature incubations were performed in either water baths or environmental chambers covering the range of $442{ }^{\circ} \mathrm{C}$ using M1N-lactate supplemented with $0.001 \%$ CAA as the growth media. All growth characterizations were performed in duplicate $125 \mathrm{ml}$ Erlenmeyer flasks with vigorous agitation (150 r.p.m.).

Morphological and microscopic analysis. The size and shape of the ANG-SQ1 ${ }^{\mathrm{T}}$ cells were determined by phase-contrast and transmission electron microscopy (TEM). Photographs of living cells were obtained using wet mounts. Motility was ascertained by the direct microscopic observation of 24-hold culture in M1N/lactate plus CAA. Flagellar staining was performed using the Flagella Stain (Carr-Scarborough). Cells were stained for $5 \mathrm{~min}$ prior to viewing at $2000 \times$ magnification. Gram staining was performed as previously described (Murray et al., 1994). The methods of Fox et al. (1995) [a $1.0 \%(\mathrm{v} / \mathrm{v})$ phosphotungstic acid (PTA) solution ( $\mathrm{pH}$ 6.6)] were used to negatively stain and view the flagella under TEM. Cross-sections were prepared as follows: cells were fixed in $2 \cdot 5 / 0 \cdot 1 \%(\mathrm{w} / \mathrm{w})$ glutaraldehyde $/ \mathrm{OsO}_{4}$ solution for $1 \mathrm{~h}$ (Owen et al., 1990), collected by centrifugation, rinsed twice in $0.01 \mathrm{M}$ HEPES ( $\mathrm{pH} \mathrm{6.8)}$ ) and post-fixed in a $2.0 \%(\mathrm{w} / \mathrm{v}) \mathrm{OsO}_{4}$ solution. After two additional HEPES rinses, the cell pellet was collected by centrifugation into Point-Beem capsules and embedded in $1.5 \%(\mathrm{w} / \mathrm{v})$ agar. The cells were then dehydrated using a graded acetone series and embedded in Spurr resin (Electron Microscope Sciences). Ultrathin sections were obtained with an RMC 
Table 1. DNA-DNA hybridization of S. pealeana ANGSQ1 ${ }^{\top}$ to other Shewanella species

\begin{tabular}{|c|c|c|}
\hline Bacterium & Strain no. & Similarity (\%) \\
\hline S. algae & ATCC 51192 & $37 \cdot 6$ \\
\hline S. amazonensis & ATCC $700329^{\mathrm{T}}$ & $27 \cdot 3^{*}$ \\
\hline S. benthica & ATCC $43992^{\mathrm{T}}$ & $29 \cdot 4$ \\
\hline S. gelidimarina & ACAM $456^{\mathrm{T}}$ & $25 \cdot 3+$ \\
\hline S. hanedai & ATCC $33224^{\mathrm{T}}$ & $26 \cdot 4$ \\
\hline S. putrefaciens & ATCC $8071^{\mathrm{T}}$ & $21 \cdot 5$ \\
\hline S. woodyi & $\mathrm{MS}-32^{\mathrm{T}}$ & $23 \cdot 0$ \\
\hline
\end{tabular}

* Data from Venkateswaran et al. (1998).

$\dagger$ Data provided by M. Satomi (personal communication).

MT-7000 ultramicrotome fitted with a diamond knife. Sections were post-stained with uranyl acetate and Reynold's lead citrate before being viewed with a Hitachi H600 TEM at $75 \mathrm{keV}$.

Physiological studies. Catalase, oxidase and other standard phenotypic analyses were performed on strain ANG-SQ1 ${ }^{\mathrm{T}}$ at $25^{\circ} \mathrm{C}$ as described elsewhere (Smibert \& Krieg, 1994). Nutritional tests were performed in $5 \mathrm{ml}$ batches of M1N in $18 \mathrm{ml}$ culture tubes at $25^{\circ} \mathrm{C}$ with vigorous agitation (150 r.p.m.). Results were recorded after $7 \mathrm{~d}$ incubation. The compounds listed in Table 2 were added to the media from sterile, $\mathrm{pH}$-neutralized $1.0 \mathrm{M}$ stock solutions and employed as sole energy sources at a final concentration of $20 \mathrm{mM}$ (except formate and ethanol; $40 \mathrm{mM}$ ). CAA, yeast extract and peptone were tested at a $0.1 \%$ final concentration added from sterile $10 \%(\mathrm{w} / \mathrm{v})$ stock solutions. Variations of Balch's vitamin mix (Balch et al., 1979), each lacking one vitamin, were added to M1N/lactate (no CAA) to test for specific requirements. A similar method was used to test the 20 amino acids. Purines, pyrimidines and other bionutrients found in CAA (Difco technical analysis) were also examined ( $25 \mu \mathrm{g} \mathrm{ml}^{-1}$ final concentration) in $\mathrm{M} 1 \mathrm{~N} /$ lactate. Iron- and manganese reduction were monitored in $\mathrm{M} 1 \mathrm{~N} /$ lactate agar plates containing $40 \mathrm{mM}$ ferric-citrate or $40 \mathrm{mM} \mathrm{MnO}$ in a soft-agar overlay, each added to the media from sterile $0.4 \mathrm{M}$ stocks prepared as described previously (Myers \& Nealson, $1988 ; 1990)$. Fresh cultures were streaked on to the ferriccitrate or stabbed into the $\mathrm{MnO}_{2}$ plates and incubated at $25^{\circ} \mathrm{C}$ in the Coy anaerobic chamber for $7 \mathrm{~d}$. Cleared zones surrounding the colony or stab were defined as areas of metal reduction. Growth by reduction of nitrate $(5 \mathrm{mM})$ or TMAO $(20 \mathrm{mM})$ was monitored by noting changes in the optical density $\left(\mathrm{OD}_{600}\right)$ of a $10 \mathrm{ml}$ culture over $7 \mathrm{~d}$ anaerobic incubation with gentle agitation $(50$ r.p.m.). Thiosulfate reduction was tested on Kligler Iron Agar (Difco) supplemented with $0.5 \mathrm{M} \mathrm{NaCl}$; the production of black colonies was considered as a positive result.

Genetic analysis. Genomic DNA was purified from ANG$\mathrm{SQ}^{\mathrm{T}}$ by the method of Marmur (1961). For the determination of the $\mathrm{G}+\mathrm{C}$ content of the $\mathrm{ANG}-\mathrm{SQ} 1^{\mathrm{T}}$ genome, the DNA was further purified on hydroxyapatite by the method of Cashion et al. (1977). The DNA was digested with P1 nuclease and the nucleotides were then dephosphorylated with bovine alkaline phosphatase (Mesbah et al., 1989). The resulting deoxyribonucleosides were analysed by HPLC within the parameters stated by Tamaoka \& Komagata (1984). DNA-DNA hybridization analysis (De Ley et al.,
1970; Escara \& Hutton, 1980) and the determination of renaturation rates (Huß et al., 1983; Jahnke, 1992) between $S$. pealeana and the other known Shewanella species were performed as previously described.

In vitro PCR amplification of the 16S rRNA gene was performed in a Minicycler (MJ Research) using the GeneAmp kit (Perkin-Elmer Cetus) and a final $\mathrm{MgCl}_{2}$ concentration of $3 \mathrm{mM}$. Primers listed in the Oligonucleotide Probe Database (http://www.cme.msu.edu) (SD-Bact-0011-a-S-17 and S-D-Bact-1492-b-A-16; Alm et al., 1996) were used to generate PCR products. Conditions for gene amplification consisted of 35 cycles of $45 \mathrm{~s}$ at $95^{\circ} \mathrm{C}, 45 \mathrm{~s}$ at $50^{\circ} \mathrm{C}$ and $2 \mathrm{~min}$ at $72^{\circ} \mathrm{C}$, with a final extension reaction of $10 \mathrm{~min}$ at $72^{\circ} \mathrm{C}$. The sequences of the amplified DNA were determined directly using the $\mathrm{IR}^{2}$ sequencing kit (LICOR, Inc.) and run on an LI-COR automated DNA sequencer. Sequences thus obtained were manually aligned with closely related and representative sequences as determined with the software utilities of the Ribosomal Database Project (RDP; Maidak et al., 1997). Phylogenetic trees and parsimony analyses were performed using PAUP version 3.2 (Swofford, 1993). Reference sequences were obtained from the RDP (Maidak et al., 1997).

Cellular fatty acid analysis. Fatty acid methyl ester (FAME) analysis was performed at MicroCheck, Inc. The isolates were cultured in M1N/lactate or Tryptic Soy Broth (TSB) at $28^{\circ} \mathrm{C}$ with gentle shaking. Fatty acids were extracted from dry cells, methylated and analysed by GC (Moss et. al., 1974 ) on a cross-linked $5 \%$ phenyl silicone capillary column. The FAME peaks were identified and quantified by comparing the results with the patterns from other microorganisms, using MIDI System software (version 3.2). The relative amount of each fatty acid was expressed as a percentage of the total for that strain.

\section{RESULTS}

\section{Isolation and microscopic examination of ANG-SQ1 ${ }^{\top}$}

Sulfur-reducing members of the ANG microbial community were isolated as stated in Methods. All of the numerous facultatively anaerobic sulfur reducers obtained in this manner were of a characteristic colonial appearance consistent with known Shewanella isolates (opaque salmon coloration with a mucoid surface). Cells grown in MIN/lactate and analysed by light- and phase-contrast microscopy proved to be motile, Gram-negative rods. Light microscopy also revealed that cells grown under non-optimal conditions appeared filamentous and deficient in proper segregation after division (data not shown). Flagellar staining revealed at least three polar flagella (data not shown), but the exact number could not be determined. Negative staining also presented problems. If cells were grown in liquid culture, $\mathrm{NaCl}$ from the media inhibited the staining. When cells were resuspended in buffer from an agar plate, the exopolysaccharide (EPS) produced by the colony clumped the cells on the grid (data not shown). Attempts to separate the cells from the EPS usually led to shearing of the flagella. When the cells could be separated from the EPS, four distinct flagella could be seen arising from the pole of each cell (data not shown). This feature differs from that of other Shewanella species, whose cells each have a 


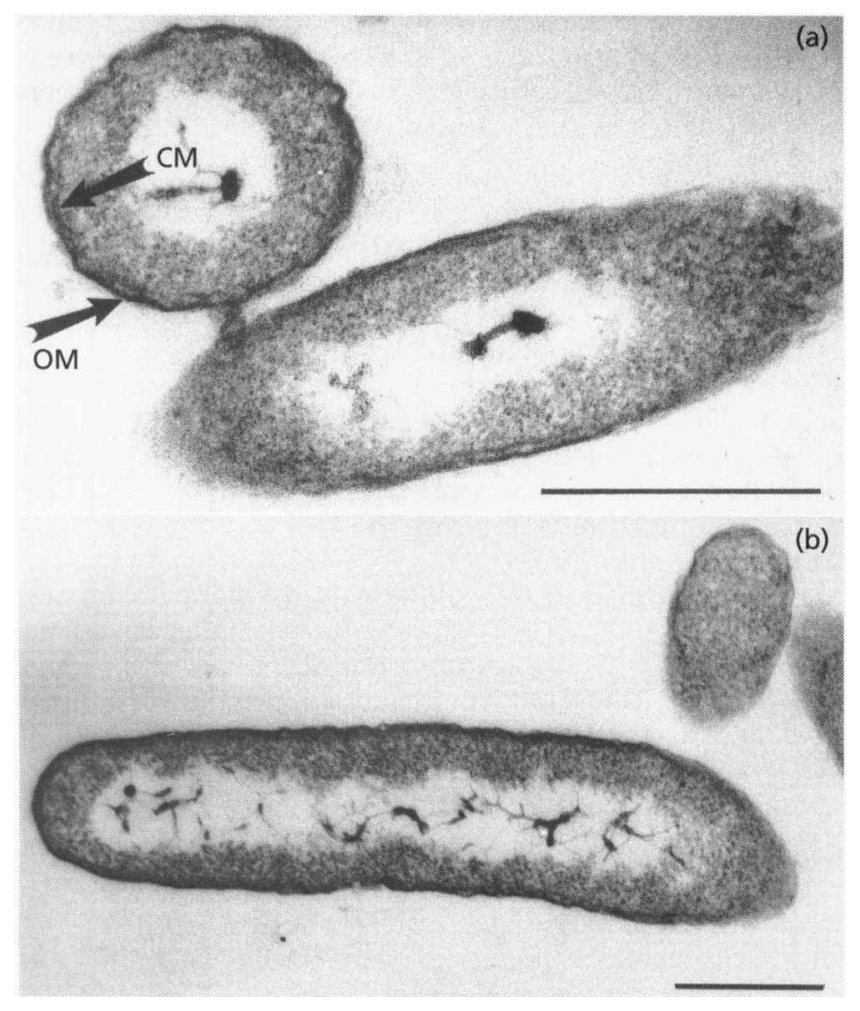

Fig. 1. Electron micrographs of thin sections of $\mathrm{ANG}-\mathrm{SQ} 1^{\top}$ grown in M1N/lactate plus CAA. Bar, $0.5 \mu \mathrm{m}$. (a) Cross-section of cells. The outer membrane (OM) and the cytoplasmic membrane (CM) are labelled with arrows. (b) Longitudinal section.

single, polar flagellum. TEM of ultrathin sections revealed that the cells were $2 \cdot 0-3 \cdot 0 \mu \mathrm{m}$ in length and $0 \cdot 4-0.6 \mu \mathrm{m}$ in diameter (Fig. 1). The cells appear to divide by binary fission (data not shown) and no visible inclusions, storage vesicles or endospores were observed.

\section{Genetic properties and phylogenetic analysis}

The 16S rRNA gene was amplified from purified genomic DNA obtained from each of the six elemental sulfur-reducing isolates by PCR and sequenced. In order to determine their phylogenetic positions, these sequences were compared to those in the RDP (Maidak et al., 1997). This query demonstrated that each of these isolates belong to the $\gamma-3$ subclass of the Proteobacteria. Five of the six isolates were similar to the known Shewanella species $(>88 \%)$, Shewanella hanedai (accession no. U91590) being the least similar because of a large number of ambiguous bases in the sequence. The sixth isolate was more closely affiliated with the genus Aeromonas. The 16S rDNA sequences of the Shewanella isolates differed by less than $1.5 \%$ (two being almost identical), suggesting that all are members of the same species. One isolate (ANG-SQ1 ${ }^{\mathrm{T}}$ ) was then selected for further analysis.
The 16S rRNA gene sequences were further compared with other members of the $\gamma-3$ subclass of Proteobacteria, which includes Alteromonas, Vibrio and Shewanella. Their phylogenetic relationships were analysed using several different subdomains of the $16 \mathrm{~S}$ sequence. Neighbour-joining analysis with Felsenstein distance corrections on these subsets are summarized in Fig. 2. All three sets of analysis gave similar phylogenetic topologies. Of the Shewanella species described, strain ANG-SQ1 ${ }^{\mathrm{T}}$ was most closely related to Shewanella gelidimarina (ACAM 456), at 97.0\% similarity. S. hanedai (ATCC 33224) was the most distantly related member of this group, with a similarity level of $88.6 \%$.

The overall DNA $\mathrm{G}+\mathrm{C}$ composition for the known Shewanella species ranges from 40 to $54 \mathrm{~mol} \%$ (Vogel et al., 1997). ANG-SQ1 ${ }^{\mathrm{T}}$ has a $\mathrm{G}+\mathrm{C}$ content of $45.0 \mathrm{~mol} \%$, which places it within the range that is typical for the Shewanella putrefaciens group of species (43.0-47.0 mol \%; Vogel et al., 1997). The direct comparison of the $\mathrm{G}+\mathrm{C}$ content of $\mathrm{ANG}-\mathrm{SQ} 1^{\mathrm{T}}$ to $S$. gelidimarina (48.0 mol \%; Table 2) supports our view that ANG-SQ ${ }^{\mathrm{T}}$ and ACAM 456 are different species.

DNA-DNA hybridization analysis between $S$. pealeana and the other characterized Shewanella species is presented in Table 1. The percentage similarity of $\mathrm{ANG}-\mathrm{SQ} 1^{\mathrm{T}} \mathrm{DNA}$ ranged from $37.6 \%$ (Shewanella algae) to $21.5 \%$ (S. putrefaciens), indicating that $S$. pealeana is distinct from the other species. S. gelidimarina (ACAM 456), the member of this group which is the most closely related phylogenetically to ANG-SQ1 ${ }^{\mathrm{T}}$, showed $25 \cdot 3 \%$ similarity (Table 1). Shewanella baltica DNA was unavailable for this comparison.

\section{Growth conditions}

As strain $\mathrm{ANG}-\mathrm{SQI}^{\mathrm{T}}$ is a marine isolate, the organism was tested for growth on $\mathrm{NaCl}$ concentrations ranging from 0.0 to $1.75 \mathrm{M}$. The isolate displayed an obligate requirement for $\mathrm{NaCl}$ and grew on levels of between 0.125 and $0.75 \mathrm{M}, 0.5 \mathrm{M}$ being optimal (data not shown). The strain grew when the starting $\mathrm{pH}$ was between 6.0 and 8.0 , with optima of $\mathrm{pH} 7.0$ for growth rate and $\mathrm{pH} 6.0$ for total biomass (data not shown). Over the course of this experiment, the $\mathrm{pH}$ of the culture increased significantly $(>1.0$ unit, data not shown), possibly explaining the disparity between the optima for growth rate and biomass. ANG-SQ $1^{\mathrm{T}}$ grew at temperatures of between 4 and $30^{\circ} \mathrm{C} ; 30^{\circ} \mathrm{C}$ led to the fastest doubling time. However, cultures grown at $25^{\circ} \mathrm{C}$ ultimately produced higher yields of cellular biomass (data not shown).

\section{Physiological and biochemical characteristics}

Initial studies indicated that these isolates grew poorly on nutrient-rich solid media, such as LB. On such plates, spontaneous mutants of a deeper orange colour 


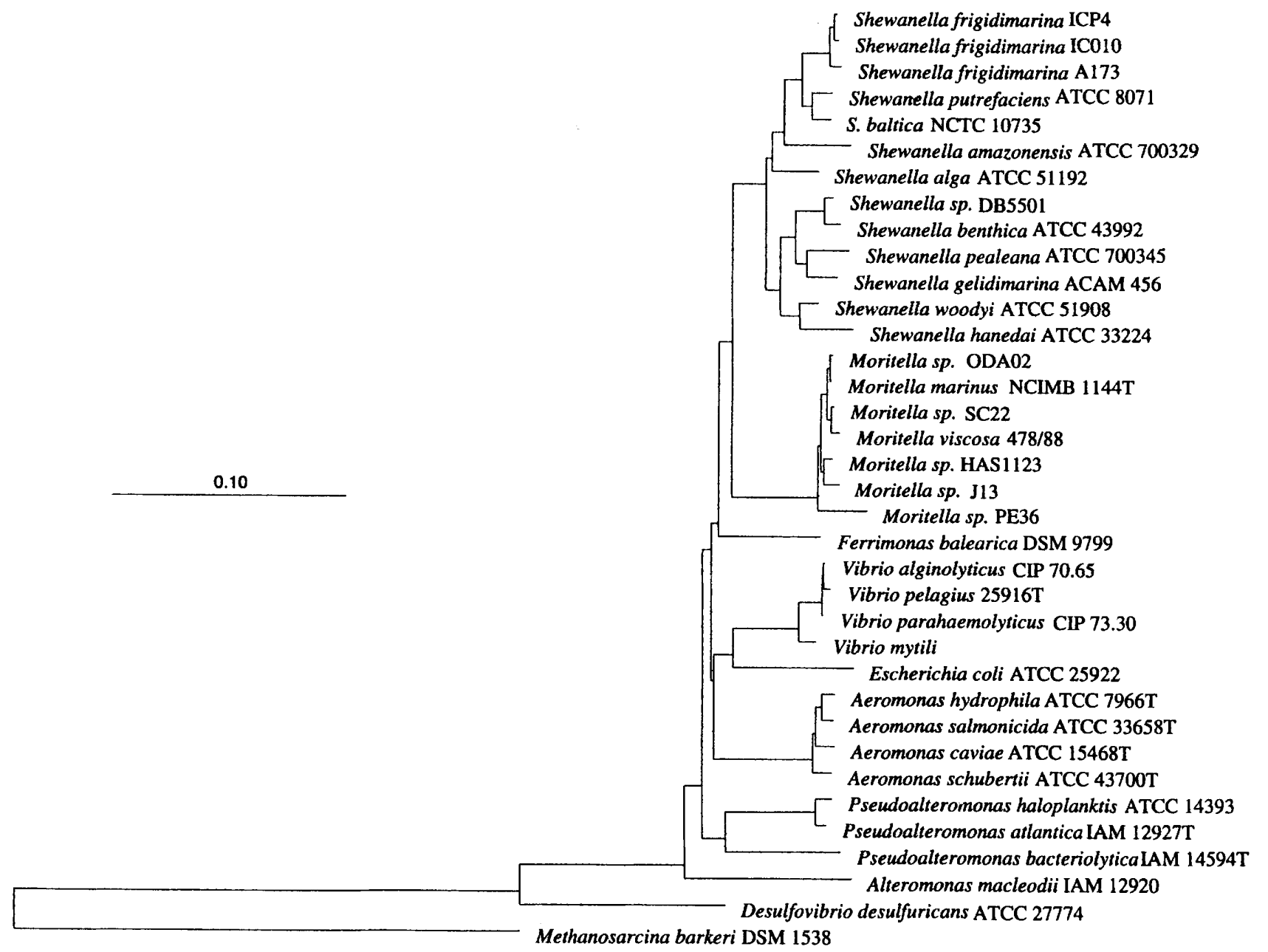

Fig. 2. Phylogenetic tree based on $16 \mathrm{~S}$ rRNA gene comparisons between members of the $\gamma$-subclass of the class Proteobacteria and ANG-SQ1 ${ }^{\top}$. The branching pattern was generated using the neighbour-joining method with Felsenstein distance corrections. The GenBank accession numbers are as follows: $A$. caviae ATCC15468 ${ }^{\top}(X 74674), A$. hydrophila ATCC $7966^{\top}$ (X74677), A. salmonicida ATCC $33658^{\top}$ (X74681), A. schubertii ATCC $43700^{\top}$ (X74682), A. macleodii IAM 12920 (X82145), D. desulfuricans ATCC 27774 (M34113), E. coli ATCC 25922 (X080724), F. balearica DSM 9799 (X93021), M. barkeri DSM 1538 (M59144), Moritella sp. HAS1123 (AB011353), Moritella sp. PE36 (U91587), Moritella sp. ODA02 (AB011353), Moritella sp. SC22 (AB011361), Moritella sp. J13 (AB011355), M. marinus (X82142), M. viscosa 486/88 (M59144), P. atlantica IAM 12927 ${ }^{\top}$ (X82134), P. bacteriolytica IAM14594 (D89929), P. haloplanktis ATCC 14393 (X67024), S. frigidimarina A173 (U85902), S. algae ATCC 51192 (AF005249 Z95846), S. amazonensis ATCC 700329 (AF005248 Z95849), S. baltica NCTC 10735 (AJ000214), S. benthica ATCC 43992 (X82131), S. frigidimarina ICP4 (U85905), S. frigidimarina IC010 (U85906), S. gelidimarina ACAM 456 (U85907), S. hanedai ATCC 33224 (U91590), S. pealeana ATCC 700345 (AF011335), S. putrefaciens ATCC $8071^{\top}$ (X82133), Shewanella sp. (DB5501 D21229), S. woodyi ATCC 51908 (AF003549), V. alginolyticus CIP 70.65 (X74691), V. mytili (X99761), V. parahaemolyticus CIP73.30 (X74721), V. pelagius ATCC $43700^{\top}(X 74722)$.

often arose which could be transferred to fresh LB agar plates, whereas the paler orange/red, wild-type colonies could not. This problem was abolished when ANG-SQ1 ${ }^{\mathrm{T}}$ was cultured on marine broth plates or grown in liquid M1N/lactate media. Strain ANG$S Q 1^{\mathrm{T}}$ was catalase-, oxidase- and lipase-positive, unable to hydrolyse starch or gelatin and did not produce indole. ANG-SQ1 ${ }^{\mathrm{T}}$ was able to utilize glucose, galactose, lactate, acetate, pyruvate, glutamate, succinate, citrate, CAA, yeast extract or peptone as sole energy source under optimal aerobic conditions (Table 2). In contrast, $S$. gelidimarina can only utilize lactate, acetate or pyruvate as sole carbon source (Table 2; Bowman et al., 1997). Fructose, sorbitol, glycerol, arabinose, formate or ethanol could not be used as sole carbon source in M1N media (data not shown). ANG$\mathrm{SQ1}^{\mathrm{T}}$ was able to utilize nitrate, fumarate, TMAO, iron, manganese, thiosulfate and elemental sulfur as alternative electron acceptors in $\mathrm{M} 1 \mathrm{~N} /$ lactate under anaerobic conditions (Table 2) and avoid fermentative growth (data not shown). Initial growth studies demonstrated a requirement for CAA in minimal liquid media, suggesting an auxotrophy. The addition of a mixture containing all 20 amino acids enhanced 
Table 2. Differential biochemical characterization of S. pealeana

From references Bowman et al. (1997), Makemson et al. (1997), Venkateswaran et al. (1998) and this study.

\begin{tabular}{|c|c|c|c|c|c|}
\hline Characteristic & $\begin{array}{c}\text { S. pealeana } \\
{\text { ATCC } 700345^{\mathrm{T}}}^{\text {a }}\end{array}$ & $\begin{array}{l}\text { S. gelidimarina } \\
{\text { ACAM } 456^{\mathrm{T}}}^{-}\end{array}$ & $\begin{array}{l}\text { S. amazonensis } \\
{\text { ATCC } 700329^{\mathrm{T}}}^{\text {a }}\end{array}$ & $\begin{array}{c}\text { S. hanedai } \\
{\text { ATCC } 33224^{\mathrm{T}}}^{-}\end{array}$ & $\begin{array}{c}\text { S. woodyi } \\
\text { ATCC 51908 }\end{array}$ \\
\hline \multicolumn{6}{|l|}{ Growth temperature: } \\
\hline $4\left({ }^{\circ} \mathrm{C}\right)$ & + & + & + & + & + \\
\hline $30\left({ }^{\circ} \mathrm{C}\right)$ & + & - & + & - & - \\
\hline $\mathrm{H}_{2} \mathrm{~S}$ production (from thiosulfate) & + & + & + & + & + \\
\hline Chitinase & - & + & - & + & - \\
\hline Gelatinase & - & + & + & + & + \\
\hline \multicolumn{6}{|l|}{ Sole carbon source:* } \\
\hline D-Glucose & + & - & - & - & - \\
\hline D-Galactose & + & - & ND & + & + \\
\hline Citrate & + & - & + & - & - \\
\hline Succinate & + & - & + & - & + \\
\hline Fumarate & - & - & + & $\mathrm{ND}$ & ND \\
\hline Pyruvate & + & + & - & ND & ND \\
\hline Lactate & + & + & + & + & + \\
\hline Acetate & + & + & + & + & + \\
\hline L-Glutamate & + & - & & ND & $\mathrm{ND}$ \\
\hline CAA & + & - & + & + & + \\
\hline Yeast extract & + & ND & ND & ND & $\mathrm{ND}$ \\
\hline Peptone & + & ND & ND & ND & ND \\
\hline Anaerobic respiration & $+\dagger$ & + & + & + & + \\
\hline $\mathrm{G}+\mathrm{C}$ content $(\mathrm{mol} \%)$ & $45 \cdot 0$ & $48 \cdot 0$ & $51 \cdot 7$ & $45 \cdot 2$ & 39.0 \\
\hline
\end{tabular}

ND, Not determined.

* All carbon sources were used at $20 \mathrm{mM}$. CAA, yeast extract and peptone were added at $0 \cdot 1 \%$. Growth was monitored at $25^{\circ} \mathrm{C}$ for $7 \mathrm{~d}$.

† Screened nitrate, fumarate, TMAO, S, $\mathrm{Mn}(\mathrm{IV})$ and Fe(III) with $20 \mathrm{mM}$ lactate as the electron donor.

growth (final $\mathrm{OD}_{600}=0.4$ ) over that observed for M1N/lactate alone (final $\mathrm{OD}_{600}=<0 \cdot 1$ ), but not to the same extent as the CAA-amended cultures (final $\mathrm{OD}_{600}=>1 \cdot 0$ ). This suggested that some constituent(s) of CAA, other than the amino acids per se, was/were responsible for the additional growth stimulation. Variations of Balch's vitamin mix were tested as supplements but failed to enhance growth. Purines, pyrimidines and inositol, which are also present in CAA, failed to enhance growth; the addition of guanine proved inhibitory (data not shown). One notable exception was the addition of choline chloride, the salt of a compound used by eukaryotic cells as a growth factor and lipid 'building block' (Jukes, 1979). Supplementation with choline chloride allowed ANG$\mathrm{SQ} 1^{\mathrm{T}}$ to grow in $\mathrm{M} 1 \mathrm{~N} /$ lactate alone (final $\mathrm{OD}_{600}=$ $0.4)$ and growth was comparable to CAA-amended cultures when the amino acid mix was also added. Given the growth requirement for choline, amino acids were tested as groups based on their chemical properties (charged, hydrophobic, etc.) in the presence of choline chloride. From this initial screen, the mixes containing either the hydrophobic amino acids (valine, isoleucine, serine and proline) or the uncharged amino acids (alanine glycine, leucine and lysine) enhanced
ANG-SQ1 ${ }^{\mathrm{T}}$ growth in the presence of choline. Two distinct biosynthetic pathways are responsible for the synthesis of most of the amino acids contained in these two groups [isoleucine, leucine, valine (ILV) and glycine, serine (GS)]. These five amino acids were tested both individually and in their biosynthetic groups to determine which are required for ANG$\mathrm{SQ} 1^{\mathrm{T}}$ growth. From this analysis, the ILV biosynthetic group seems to be the necessary growth supplement, leucine being the one that provides the greatest enhancement (data not shown). These data, combined with the observations that $S$. gelidimarina required no nutritional supplements (Bowman et al., 1997), further support our view that these strains are unique.

\section{Cellular fatty acid composition}

Following saponification, the following major fatty acids were detected in strain ANG-SQ $1^{\mathrm{T}}: 12: 0, \mathrm{i} 13: 0$, i13.0 3-OH, 14:0, 15:0, i15:0, 16:0, 17:0, 17:1 $\omega 8 c$ and $18: 1 \omega 9 c$ (Table 3). Other major fatty acids which were present in $A N G-S Q 1^{\mathrm{T}}$ (but could not be quantified owing to poor resolution of the chromatogram)

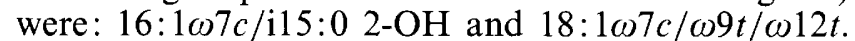
No match could be determined during comparisons 
Table 3. Fatty acid composition (\%) of Shewanella species

Data from Bowman et al. (1997), Makemson et al. (1997), Venkateswaran et al. (1998) and this study. Tr, Trace (<0.1\%). NR, Not resolved: set of fatty acid esters which could not be resolved; the total level of these esters was $2.92 \%$ of the total profile.

\begin{tabular}{|c|c|c|c|c|c|c|c|c|}
\hline Fatty acid & S. pealeana & S. putrefaciens & S. algae & S. gelidimarina & S. benthica & S. amazonensis & S. hanedai & S. woodyi \\
\hline $12: 0$ & $4 \cdot 0$ & $0 \cdot 1-2 \cdot 6$ & $0 \cdot 1$ & $0 \cdot 3-0 \cdot 7$ & $0 \cdot 2-1 \cdot 4$ & & $0 \cdot 1-2 \cdot 6$ & $4 \cdot 13$ \\
\hline $\mathrm{i} 13: 0$ & $13 \cdot 8$ & $1 \cdot 0-3 \cdot 6$ & 0.5 & $5 \cdot 4-15 \cdot 8$ & $2 \cdot 8-8 \cdot 9$ & $4 \cdot 7$ & $5 \cdot 1-7 \cdot 7$ & $10 \cdot 04$ \\
\hline $13: 0$ & $0 \cdot 9$ & $0.0-0.5$ & $0 \cdot 1$ & $\operatorname{Tr}-1 \cdot 3$ & $0-0 \cdot 3$ & & $0-0 \cdot 3$ & $0 \cdot 87$ \\
\hline $12: 03-\mathrm{OH}$ & $1 \cdot 5$ & & & & & & & \\
\hline i14:0 & $1 \cdot 2$ & $\operatorname{Tr}-0.3$ & $0 \cdot 8$ & $0 \cdot 1-0 \cdot 6$ & $0 \cdot 7-1.0$ & $1 \cdot 5$ & $0 \cdot 1-0 \cdot 4$ & \\
\hline $14: 1 \omega 7 c$ & & $0 \cdot 0-\operatorname{Tr}$ & $\operatorname{Tr}$ & $0 \cdot 3-0.8$ & $0 \cdot 1-0 \cdot 5$ & & $0-\operatorname{Tr}$ & \\
\hline $14: 0$ & $5 \cdot 6$ & $1 \cdot 5-5 \cdot 9$ & 0.7 & $3 \cdot 8-4 \cdot 4$ & $11 \cdot 0-11 \cdot 9$ & $1 \cdot 4$ & $7 \cdot 6-10 \cdot 1$ & $4 \cdot 65$ \\
\hline i13:0 3-OH & $3 \cdot 2$ & & & & & & & \\
\hline $\mathrm{i} 15: 0$ & $16 \cdot 0$ & $8 \cdot 8-24 \cdot 2$ & $17 \cdot 8$ & $8 \cdot 3-11 \cdot 6$ & $4 \cdot 4-6 \cdot 2$ & $26 \cdot 7$ & $7 \cdot 9-8 \cdot 2$ & $19 \cdot 53$ \\
\hline $15: 0$ & $2 \cdot 5$ & $1 \cdot 4-7 \cdot 5$ & $4 \cdot 0$ & $1 \cdot 6-6 \cdot 7$ & $0.4-0.9$ & $9 \cdot 2$ & $2 \cdot 9-3 \cdot 5$ & $4 \cdot 05$ \\
\hline $15: 1 \omega 8 c$ & & $0 \cdot 0-0.7$ & $\operatorname{Tr}$ & $0.7-1 \cdot 7$ & & & $0-0 \cdot 1$ & \\
\hline $15: 1 \omega 6 c$ & & $0.0-0.3$ & $\operatorname{Tr}$ & $0 \cdot 4-1 \cdot 7$ & $0-0.2$ & $0 \cdot 8$ & $0-0.5$ & \\
\hline i16:0 & & $0 \cdot 0-\mathrm{Tr}$ & $1 \cdot 1$ & & & 1.4 & & \\
\hline $16: 1 \omega 9 c$ & & $0 \cdot 0-2 \cdot 4$ & & $0-0.7$ & & $0 \cdot 7$ & & $17 \cdot 26$ \\
\hline $16: 1 \omega 7 c$ & $20 \cdot 1$ & $25 \cdot 2-31 \cdot 4$ & $16 \cdot 3$ & $27 \cdot 4-37 \cdot 0$ & $24 \cdot 0-43 \cdot 9$ & $14 \cdot 7$ & $25 \cdot 0-33 \cdot 1$ & \\
\hline $16: 1 \omega 7 t$ & & $1 \cdot 0-1 \cdot 7$ & $0 \cdot 2$ & $0-0.1$ & & & & \\
\hline $16: 0$ & $18 \cdot 6$ & $27 \cdot 9-31 \cdot 0$ & $13 \cdot 3$ & $6 \cdot 4-11 \cdot 1$ & $10.6-11 \cdot 6$ & $6 \cdot 1$ & $12 \cdot 2-15 \cdot 0$ & $20 \cdot 81$ \\
\hline i17:0 & $1 \cdot 1$ & $\operatorname{Tr}-1.6$ & $0 \cdot 5$ & $0 \cdot 1-0 \cdot 4$ & $0 \cdot 1-1.5$ & $1 \cdot 8$ & $0 \cdot 8-2 \cdot 4$ & $1 \cdot 66$ \\
\hline $17: 1 \omega 8 c$ & $2 \cdot 8$ & $2 \cdot 7-3 \cdot 7$ & $14 \cdot 7$ & $1 \cdot 9-4.2$ & $1 \cdot 6-6 \cdot 6$ & $23 \cdot 4$ & $0 \cdot 5-1 \cdot 5$ & \\
\hline $17: 1 \omega 6 c$ & & $0 \cdot 0-0.4$ & $1 \cdot 4$ & $0.8-0.9$ & $0-1 \cdot 2$ & $2 \cdot 4$ & $0.3-0.5$ & \\
\hline $17: 0$ & $1 \cdot 5$ & $0 \cdot 6-1 \cdot 6$ & $1 \cdot 4$ & $0.4-0.5$ & $0 \cdot 5-8 \cdot 1$ & $3 \cdot 9$ & $0 \cdot 6-1 \cdot 0$ & $1 \cdot 3$ \\
\hline $18: 1 \omega 9 c$ & $2 \cdot 4$ & $1 \cdot 1-3 \cdot 6$ & $6 \cdot 0$ & $0.3-0.9$ & $0-0.2$ & $1 \cdot 4$ & $0 \cdot 2-0 \cdot 8$ & 0.98 \\
\hline $18: 1 \omega 9 t$ & NR & & & & & & & \\
\hline $18: 1 \omega 7 c$ & NR & $2.4-3.9$ & $7 \cdot 2$ & $1 \cdot 0-8 \cdot 4$ & $0-1 \cdot 7$ & $4 \cdot 5$ & $2 \cdot 2-3 \cdot 7$ & \\
\hline $18: 1 \omega 7 t$ & & & $0 \cdot 2$ & & & & & \\
\hline $18: 1 \omega 12 t$ & NR & & & & & & & \\
\hline $18: 0$ & 0.97 & $0 \cdot 5-3 \cdot 2$ & $2 \cdot 7$ & $0 \cdot 1-0 \cdot 2$ & $0-0.5$ & $0 \cdot 1$ & $0-0.4$ & \\
\hline $20: 5 \omega 3$ & & & & $11 \cdot 7-16 \cdot 0$ & $15 \cdot 8-18 \cdot 5$ & & $19 \cdot 1-22 \cdot 2$ & \\
\hline Other & 0.97 & $0.0-0.8$ & $2 \cdot 7$ & $0-08$ & & & $0-0 \cdot 3$ & $6 \cdot 25$ \\
\hline
\end{tabular}

performed against the database at MicroCheck, Inc. The organism in this database with the closest similarity to $\mathrm{ANG}-\mathrm{SQ}{ }^{\mathrm{T}}$ was the non-type strain of Brevibacterium acetylicum-GC sub-group (distance coefficient, 11.9). In addition, ANG-SQ1 ${ }^{\mathrm{T}}$ lacked the polyunsaturated fatty acid eicosapentanoic acid $(20: 5 \omega 3)$, a major constituent of the whole-cell fatty acids of its closest relative, $S$. gelidimarina (Table 3 ). This further supports our contention that these two organisms are unique species.

\section{DISCUSSION}

Six bacterial isolates representing one of the cultivable bacterial types from the ANG of the squid $L$. peale were purified for this study. All were initially screened on the basis of elemental sulfur reduction and all shared a common colony and cell morphology. One isolate $\left(\mathrm{ANG}-\mathrm{SQ1}^{\mathrm{T}}\right.$ ) was chosen at random for detailed analysis. In this report, we make the case, based on a combination of independent molecular and phenotypic characterizations, that the isolate ANG$\mathrm{SQ} 1^{\mathrm{T}}$ falls within the genus Shewanella and represents a novel species.

Initial comparisons of the $S$. pealeana 16S rRNA sequence with those of the other known Shewanella species indicated that this organism had a close phylogenetic relationship to the others in this genus $(88.6-97 \cdot 0 \%)$. With one notable exception however, ANG-SQ1 ${ }^{\mathrm{T}}$ failed to meet the $97 \%$ homology criterion (Wayne et al., 1987) for inclusion within any of the described species. The $16 \mathrm{~S}$ rDNA sequence homology between $\mathrm{ANG}-\mathrm{SQ}^{\mathrm{T}}$ and the type strain of the new species, S. gelidimarina (Bowman et al., 1997), is in fact $97.0 \%$, a value that can neither prove nor disprove a species relationship. In a case such as this, DNA-DNA hybridization is the preferred method for clarifying ambiguous phylogenetic relationships. These experiments were performed and $S$. gelidimarina was $25 \cdot 3 \%$ similar to strain ANG-SQ1 ${ }^{\mathrm{T}}$ (Table 1 ). In addition, Venkateswaran et al. (1999) have reported that, on the basis of an independent molecular marker 
(gyrB, the $\beta$-subunit of DNA topoisomerase II), $S$. gelidimarina and $S$. pealeana are almost certainly unique species. Physiological, fatty acid and mol\% $\mathrm{G}+\mathrm{C}$ profiles for these two organisms also support the conclusion that $S$. pealeana and $S$. gelidimarina are distinct from one another.

The facultatively anaerobic sulfur-reducing ANG isolates were Gram-negative, motile rods $(2 \cdot 0-3 \cdot 0 \mu \mathrm{m}$ long, $0.4-0.6 \mu \mathrm{m}$ in diameter) with polar flagella. Growth on marine broth agar produced salmoncoloured colonies $2 \mathrm{~mm}$ in diameter after several days of growth. S. pealeana is a non-fermentative organism that can utilize glucose, galactose, lactate, acetate, pyruvate, glutamate, citrate, succinate, CAA, yeast extract or peptone as sole energy source under aerobic conditions. Anaerobically, this organism performs the dissimilatory reduction of nitrate, fumarate, iron, manganese, TMAO, thiosulfate and elemental sulfur, with lactate as the electron donor. ANG-SQ1 ${ }^{\mathrm{T}}$ can grow within a wide range of salinities at mesophillic temperatures. The morphological and physiological characteristics of these isolates closely resemble those of other Shewanella species, more specifically those of the $S$. putrefaciens subclass rather than the Shewanella algae subclass (Vogel et al., 1997). 16S rRNA sequence analysis grouped these isolates with the $\gamma-3$ subclass of the Proteobacteria, their closest known relative being an organism ( $S$. gelidimarina) isolated from the Antarctic Sea (Bowman et al., 1997).

The requirement of choline chloride for cultures of $S$. pealeana in $\mathrm{M} 1 \mathrm{~N} /$ lactate media was unexpected. Choline is an important nutritional component in the diet of higher eukaryotes, which employ it in the synthesis of phosphatidylcholine, a membrane phospholipid (Jukes, 1979). However, the synthesis of phosphatidylcholine by most prokaryotes for their membranes has not been demonstrated (Moat, 1979), suggesting that this possible use for choline is possible but unlikely. The growth of several Gram-positive organisms in the absence (Horne \& Tomasz, 1993) or in an excess (Podvin et al., 1988) of choline was shown to result in severely affected cell shape, cell division and overall physiology. Perhaps a high choline content in the yeast extract of LB affected ANG-SQ1 ${ }^{\mathrm{T}}$, leading to celldivision defects (data not shown) and eventual cell death. Another possibility is that choline may serve as a precursor to glycine-betaine, a compatible solute which is known to accumulate in cells in response to stressful conditions such as high salt (Csonka \& Hanson, 1991) or low temperatures (Ko et al., 1994). Most micro-organisms lack the ability to synthesize glycine-betaine, but it can be readily transported across the cytoplasmic membrane (Boch et al., 1994). The glycine-betaine biosynthesis operon encoding the choline oxidase gene $(\operatorname{cod} A)$ has been recently cloned and sequenced from a halophile (Cánovas et al., 1996). It has been subsequently expressed in other organisms (Deshnium et al., 1997; Hayashi et al., 1997) to enhance tolerance to salt and cold stress. An excellent starting point for future studies would be to determine whether this operon is present in the $S$. pealeana genome. Glycine-betaine also can be further metabolized into methionine, potentially to supplement an auxotrophy. However, as methionine itself did not enhance the growth of ANG-SQ ${ }^{\mathrm{T}}$ in $\mathrm{M} 1 \mathrm{~N} /$ lactate media, this explanation seems improbable. The lipase activity demonstrated by $S$. pealeana may be used for the extraction of choline from Loligo membranes for these purposes. However, there are no experimental data to support this hypothesis. Choline could also play a role in host-micro-organism interactions. Choline-binding proteins have been identified on the cell surface of several micro-organisms (Sanchez-Beato \& Garcia, 1996). If these membrane proteins are present, they could provide a matrix for a specific interaction between the phosphatidylcholine present in the Loligo membranes and ANG-SQ1 ${ }^{\mathrm{T}}$. This may facilitate the colonization of the ANGs by this Shewanella species, hence explaining the repeated isolation of related organisms from the gland (Bloodgood, 1977; Getzel, 1934).

At present, the role of the microbial community within the Loligo ANG remains undetermined. The function of the ANG is unknown but histological studies have shown that the gland exhibits a secretory cycle associated with maturation of the squid (Lum-Kong, 1992). Some members of the genus Alteromonas can produce antibiotic compounds (Gauthier, 1976; Gauthier \& Breittmayer, 1979). Because the ANG is a reproductive organ and located immediately adjacent to the eggproducing nidamental glands, the antibiotic activities of Alteromonas-like species could provide protection for the cephalopod eggs once laid. Previous studies of other Loligo species have demonstrated that a dense culture of bacteria is arranged in the egg capsule sheath which appears to help to protect the embryos from animal, fungal and microbial predation during incubation (Biggs \& Epel, 1991). Strains closely related to $S$. pealeana have been isolated recently from the egg sheath of $L$. pealei as well as from the ANG from the Pacific squid Loligo opalescens (Barbieri et al., 1999). This further supports the hypothesized mutualistic role for the ANG micro-organisms in the cephalopod life cycle (Barbieri et al., 1996). Because Shewanella species were once classified as Altermonas species (Coyne et al., 1989; MacDonell \& Colwell, 1985), a genus known for antibiotic production, it seems plausible that ANG-SQ1 ${ }^{\mathrm{T}}$ may also produce antibiotics. Another possibility is that ANG-SQ1 ${ }^{\mathrm{T}}$ could synthesize allelochemicals that would affect its host, competitors or predators (as observed with crustacean embryo-associated micro-organisms; Gil-Turnes et al., 1989). Initial assays for antimicrobial activity by ANG-SQ $1^{\mathrm{T}}$ have demonstrated a weak inhibition of several marine pathogens (Barbieri et al., 1997). Whether this inhibition is the result of antibiotic or allelochemical activities is, at present, unknown. The roles of $S$. pealeana in the ANG, as well as the participation of choline in this relationship, are ideal starting points for future studies. The evidence we 
Shewanella pealeana sp. nov.

present here suggests that these isolates represent a new Shewanella species. We propose the name Shewanella pealeana for this organism, reflecting its relationship with Loligo pealei.

\section{Description of Shewanella pealeana sp. nov.}

Shewanella pealeana (peal'le.ana. M.L. adj. pealeana from peale or pealei, the species name of the squid Loligo paelei with which the bacterium is associated).

Cells are Gram-negative, polarly flagellated, rods $2.0-3.0 \mu \mathrm{m}$ long and $0.4-0.6 \mu \mathrm{m}$ wide. Circular, opaque, salmon-coloured colonies are formed after $2 \mathrm{~d}$ on marine broth agar at $25^{\circ} \mathrm{C}$. Catalase-, oxidase- and lipase-positive. Amylase- and gelatinase-negative. Growth occurs at temperatures of $4-30^{\circ} \mathrm{C}$ (optimal temperature for biomass, $25^{\circ} \mathrm{C}$ ) in the presence of $\mathrm{NaCl}$ concentrations ranging from $0 \cdot 125-0 \cdot 75 \mathrm{M}$ (optimum $\mathrm{NaCl}$ concentration, $0.5 \mathrm{M}$ ) and within a $\mathrm{pH}$ range of 68 (optimum starting $\mathrm{pH}, 7 \cdot 0$ ). Glucose, galactose, lactate, acetate, pyruvate, citrate, succinate, glutamate, Casamino acids, yeast extract and peptone are used as energy sources aerobically. Fructose, glycerol, sorbitol, arabinose, formate and ethanol are not utilized. An obligate respirer using nitrate, fumarate, iron, manganese, TMAO, thiosulfate and elemental sulfur as alternate electron acceptors anaerobically with lactate. Choline chloride appears to be an essential growth factor in minimal media. The main cellular fatty acids are iso-branched acids, which account for $35.2 \%$ of the total fatty acids. The $\mathrm{G}+\mathrm{C}$ content of the genome is $45.0 \mathrm{~mol} \%$. The type strain, Shewanella pealeana ANG-SQ1 ${ }^{\mathrm{T}}$, was isolated from the accessory nidamental gland of the squid Loligo pealei. This isolate was a member of a microbial community harboured within the ANG and was selected for its ability to reduce elemental sulfur. Strain ANG-SQ1 $1^{\mathrm{T}}$ has been deposited in the American Type Culture Collection as strain ATCC $700345^{\mathrm{T}}$.

\section{ACKNOWLEDGEMENTS}

We would like to thank Professors Abigail Salyers and Ed Leadbetter, co-directors of the 1996 Microbial Diversity Course, for providing the initial direction for this study. We also thank the personnel of the Marine Resources Center at the Marine Biological Laboratory for providing the squid specimens, and Dr Jay Gulledge for his role in the isolation of the ANG strains. We appreciate the assistance of Brett Baker (CGLS) and Jutta Burghardt (DSMZ), both of whom facilitated several experiments. We would also like to acknowledge Dr Kasthuri Venkateswaran for his invaluable assistance concerning the gyr $B$ gene analysis. We would also like to express our appreciation to Jolanta Nunley (The University of Alabama) for her expertise with negative staining. We especially thank Dr Masataka Satomi for performing the DNA-DNA hybridizations between $S$. pealeana and S. gelidimarina. Finally, we would like to thank Dr Hans Trüper for his helpful suggestions on the naming of this new organism. E. B. was funded by a fellowship from the University of Urbino (398/1989 Protocol N. 22204) and
B. J.M. was suppported by Grant DEB-9615356 from the National Science Foundation. This work is a follow-up to research performed during the 1996 Microbial Diversity Course at the Marine Biology Laboratories, Woods Hole, MA, USA.

\section{REFERENCES}

Aguirre, A. A., Balazs, H., Zimmerman, B. \& Spraker, T. R. (1994). Evaluation of Hawaiian green turtles (Chelonia mydas) for potential pathogens associated with fibropapillomas. $J$ Wild Dis 30, 8-15.

Alm, E. W., Oerther, D. B., Larsen, N., Stahl, D. A. \& Raskin, L. (1996). The Oligonucleotide Probe Database. Appl Environ Microbiol 62, 3557-3559.

Balch, W. E., Fox, G. E., Magrum, L. J., Woese, C. R. \& Wolfe, R. S. (1979). Methanogens: re-evaluation of a unique biological group. Microbiol Rev 43, 260296.

Barbieri, E., Gulledge, J., Moser, D. P. \& Chien, C.-C. (1996). New evidence for bacterial diversity in the accessory nidamental gland of the squid Loligo pealei. Biol Bull 191, 316-317.

Barbieri, E., Barry, K., Child, A. \& Wainwright, N. (1997). Antimicrobial activity in the microbial community of the accessory nidamental gland and egg membranes of Loligo pealei (Cephalopoda: Loliginidae). Biol Bull 193, 275-276.

Barbieri, E., Paster, B. J., Hughes, D., Zurek, L., Moser, D. P., Teske, A. \& Sogin, M. L. (1999). The accessory nidamental gland and egg capsules of the squid Loligo pealei (Cephalopoda: Loliginidae) are dominated by alpha protcobacterial endobionts. Appl Environ Microbiol (in press).

Biggs, J. \& Epel, D. (1991). Egg capsule sheath of Loligo opalescens Berry: structure and association with bactcria. $J$ Exp Zool 259, 263-267.

Bloodgood, A. R. (1977). The squid accessory nidamental gland: ultrastructure and association with bacteria. Tissue Cell $\mathbf{9}$, 197-208.

Boch, J., Kempf, B. \& Bremer, E. (1994). Osmoregulation in Bacillus subtilis: synthesis of the osmoprotectant glycinebetaine from exogenously provided choline. I Bacteriol 176, $5364-5371$

Bowman, J. P., McCammon, S. A., Nichols, D. S., Skerratt, J. H., Rea, S. M., Nichols, P. D. \& McMeekin, T. A. (1997). Shewanella gelidimarina sp. nov. and Shewanella frigidimarina sp. nov., novel Antarctic species with the ability to produce eicosapentaenoic acid $(20: 503)$ and grow anaerobically by dissimilatory Fe(III) reduction. Int I Syst Bacteriol 47, 1040-1047.

Cánovas, D., Vargas, C., Csonka, L. N., Ventosa, A. \& Nieto, J. J. (1996). Osmoprotectants in Halomonas elongata: high-affinity betaine transport system and choline-betaine pathway. J Bacteriol 178, 7221-7226.

Cashion, P., Holder-Franklin, M. A., McCully, J. \& Franklin, M. (1977). A rapid method for the base ratio determination of bacterial DNA. Anal Biochem 81, 461-466.

Coyne, V. E., Pillidge, C. J., Sledjeski, D. D., Hori, H., Ortiz-Conde, B. A., Muir, D. G., Weiner, R. M. \& Colwell, R. R. (1989). Reclassification of Alteromonas colvelliana to the genus Shewanella by DNA-DNA hybridization, serology and 5S ribosomal RNA sequence data. Syst Appl Microbiol 12, 275-279.

Csonka, L. \& Hanson, A. D. (1991). Prokaryotic osmoregulation genetics and physiology. Annu Rev Microbiol 45, 569-606.

Curtiss, C. F. (1931). Bacteriology of butter. IV. Bacteriological studies on the surface taint of butter. Research Bulletin $\# 145$. 
Ames, IA : Agricultural Research Station, Iowa State College of Agriculture and Mechanical Arts.

De Ley, J. H., Cattoir, H. \& Reynaerts, A. (1970). The quantitative measurement of DNA rehybridisation from renaturation rates. Eur J Biochem 12, 133-142.

Deshnium, P., Gombos, A., Nishiyama, Y. \& Murata, N. (1997). The action in vivo of glycine betaine in enhancement of tolerance of Synechococcus sp. strain PCC7942 to low temperature. J Bacteriol 179, 339-344.

Escara, J. F. \& Hutton, J. R. (1980). Thermal stability and renaturation of DNA in dimethylsulphoxide solutions: acceleration of renaturation rate. Biopolymers 19, 1315-1327.

Fox, J. G., Yan, L. L., Dewhirst, F. E., Paster, B. J., Shames, B., Murphy, J. C., Hayward, A., Belcher, J. C. \& Mendes, E. N. (1995). Helicobacter bilis sp. nov., a novel Helicobacter species isolated from bile, livers, and intestines of aged, inbred mice. $J$ Clin Microbiol 33, 445-454.

Gauthier, M. J. (1976). Altermonas rubra sp. nov., a new marine antibiotic-producing bacterium. Int J Sys Bacteriol 26, 459-466.

Gauthier, M. J. \& Breittmayer, V. A. (1979). A new antibioticproducing bacterium from seawater: Alteromonas aurantia sp. nov. Int J Sys Bacteriol 29, 366-372.

Getzel, D. (1934). I microbi della ghiandola accessoria nidamentale nella Seppia officinalis. Arch Zool Ital 20, 33-43.

Gil-Turnes, M. S., Hay, M. E. \& Fenical, W. (1989). Symbiotic marine bacteria chemically defend crustacean embryos from pathogenic fungus. Science 246, 116-118.

Hayashi, H., Alia, L., Mustardy, L., Deshnium, P., Ida, M. \& Muratan, N. (1997). Transformation of Arabidopsis thaliana with the $\operatorname{cod} A$ gene for choline oxidase; accumulation of glycinebetaine and enhanced tolerance to salt and cold stress. Plant $J$ 12, 133-142.

Horne, D. S. \& Tomasz, A. (1993). Possible role of cholinecontaining teichoic acid in the maintenance of normal cell shape and physiology in Streptococcus oralis. $J$ Bacteriol 175, 1717-1722.

Huß, V. A. R., Festl, H. \& Schleifer, K.-H. (1983). Studies on the spectrophotometric determination of DNA hybridization from renaturation rates. Syst Appl Microbiol 4, 184-192.

Jahnke, K. D. (1992). BASIC computer program for evaluation of spectroscopic DNA renaturation data from GILFORD SYSTEM 2600 spectrophotometer on a PC/XT/AT type personal computer. J Microbiol Methods 15, 61-73.

Jukes, T. H. (1979). Choline. In Kirk-Othmer Encyclopedia of Chemical Technology, 3rd edn, vol. 6, pp. 19-28. Edited by H. F. Mark, D. F. Othmer, C. G. Overberger \& G. T. Seaborg. New York: Wiley.

Ko, R., Tombras, L. \& Smith, G. M. (1994). Glycine-betaine confers enhanced osmotolerance and cryotolerance on Listeria monocytogenes. $J$ Bacteriol 176, 426-431.

Lovley, D. R., Phillips, E. J. S. \& Lonergan, D. J. (1989). Hydrogen and formate oxidation coupled to dissimilatory reduction of iron or manganese by Alteromonas putrefaciens. Appl Environ Microbiol 55, 700-706.

Lum-Kong, A. (1992). A histological study of the accessory reproductive organs of female Loligo forbesi (Cephalopoda: Loliginidae). $J$ Zool Lond 226, 469-490.

Lum-Kong, A. \& Hastings, T. S. (1992). The accessory nidamental glands of Loligo forbesi (Cephalopoda: Loliginidae): characterization of symbiotic bacteria and preliminary experiments to investigate factors controlling sexual maturation. $J$ Zool Lond 228, 395-403.
MacDonell, M. T. \& Colwell, R. R. (1985). Phylogeny of Vibrionaceae, and recommendation for two new genera, Listonella and Shewanella. Syst Appl Microbiol 6, 171-182.

Maidak, B. L., Olsen, G. J., Larsen, N., Overbeek, R., McCaughey, M. J. \& Woese, C. R. (1997). The RDP (Ribosomal Database Project). Nucleic Acids Res 25, 109-111.

Makemson, J. C., Fulayfil, N. R., Landry, W., Van Ert, L. M., Wimpee, C. M., Widder, E. A. \& Case, J. F. (1997). Shewanella woodyi sp. nov., an exclusively respiratory luminous bacterium isolated from the Alboran sea. Int $J$ Syst Bacteriol 47, 1034-1039.

Marmur, J. (1961). A procedure for the isolation of deoxyribonucleic acids from microorganisms. $\mathrm{J} \mathrm{Mol} \mathrm{Biol} \mathrm{3,} \mathrm{208-218.}$

Mesbah, M., Premachandran, U. \& Whitman, W. B. (1989). Precise measurement of the $\mathrm{G}+\mathrm{C}$ content of deoxyribonucleic acid by high-performance liquid chromatography. Int $J$ Syst Bacteriol 39, 159-167.

Moat, A. G. (1979). Metabolism and biosynthesis of lipids, sterols, and aromatic compounds. In Microbial Physiology, pp. 191-228. New York: Wiley.

Moser, D. P. \& Nealson, K. H. (1996a). Growth of the facultative anaerobe Shewanella putrefaciens by elemental sulfur reduction. Appl Environ Microbiol 62, 2100-2105.

Moser, D. P. \& Nealson, K. H. (1996b). Elemental sulfur reduction in facultative anaerobes as an educational tool. A Focus on Microbiology Education, Winter, 5-6. Washington, DC: American Society for Microbiology.

Moss, C., Lambert, M. A. \& Merwin, W. H. (1974). Comparison of rapid analysis of bacterial fatty acids. Appl Microbiol 28, 80-85.

Murray, R. G. E., Doetsch, R. N. \& Robinow, C. F. (1994). Determinative and cytological light microscopy. In Methods for General and Molecular Bacteriology, pp. 21-41. Edited by P. Gerhardt, R. G. E. Murray, W. A. Wood \& N. R. Krieg. Washington, DC: American Society for Microbiology.

Myers, C. R. \& Nealson, K. H. (1988). Bacterial manganese reduction and growth with manganese oxide as the sole electron acceptor. Science 240, 1319-1321.

Myers, C. R. \& Nealson, K. H. (1990). Respiration-linked proton translocation coupled to the anaerobic reduction of manganese (IV) and iron (III) in Shewanella putrefaciens MR-1. J Bacteriol 172, 6232-6238.

Nealson, K. H. (1997). Sediment bacteria: who's there, what are they doing, and what's new? Annu Rev Earth Planet Sci 25, 403-434.

Nealson, K. H. \& Meyers, C. R. (1992). Microbial reduction of manganese and iron: new approaches to carbon cycling. Appl Environ Microbiol 58, 439-443.

Nealson, K. H., Myers, C. R. \& Wimpee, B. (1991). Isolation and identification of manganese reducing bacteria, and estimates of microbial manganese reducing potential in the Black Sea. Deep Sea Res 38, S907-S920.

Owen, H. A., Mattox, K. R. \& Stewart, K. D. (1990). Fine structure of the flagellar apparatus of Dinobryon cylindricum (Chrysophyceae). J Phycol 26, 131-141.

Parker, L. L. \& Levin, R. E. (1983). Relative incidence of Alteromonas putrefaciens and Pseudomonas putrefaciens in ground beef. Appl Environ Microbiol 45, 769-799.

Podvin, L., Reysset, G., Hubert, J. \& Sebald, M. (1988). Presence of choline in teichoic acids of Clostridium acetobutylicum N1-4 and choline inhibition of autolytic functions. J Gen Microbiol 134, 1603-1609. 
Sanchez-Beato, A. R. \& Garcia, J. L. (1996). Molecular characterization of a family of choline-binding proteins of Clostridium beijerinckii NCIB 8052 . Evolution and gene redundancy in the prokaryotic cell. Gene 180, 13-21.

Semple, K. M. \& Westlake, D. W. S. (1987). Characterization of iron reducing Alteromonas putrefaciens strains from oil field fluids. Can J Microbiol 33, 366-371.

Smibert, R. M. \& Krieg, N. R. (1994). Phenotypic characterization. In Methods for General and Molecular Bacteriology, pp. 607-654. Edited by P. Gerhardt, R. G. E. Murray, W. A. Wood \& N. R. Krieg. Washington, DC: American Society for Microbiology.

Stenström, I.-M. \& Molin, G. (1990). Classification of the spoilage flora of fish, with special reference to Shewanella putrefaciens. $J$ Appl Bacteriol 68, 601-618.

Swofford, D. L. (1993). PAUP: phylogenetic analysis using parsimony, version 3.2. Champaign, IL: Illinois Natural History Survey.

Tamaoka, J. \& Komagata, K. (1984). Determination of DNA base composition by reversed-phase high-performance liquid chromatography. FEMS Microbiol Lett 25, 125-128.
Van den Branden, C. A., Lemaire, R. J. \& Decleir, W. (1979). La glande nidamentaires accessoire de Sepia officinalis L.: analysis des pigments des bacteries symbiotiques. Annu Soc R Zool Belg 108, 123-129.

Venkateswaran, K., Dollhopf, M. E., Aller, R., Stackebrandt, E. \& Nealson, K. H. (1998). Shewanella amazonensis sp. nov., a novel metal-reducing facultative anaerobe from Amazonian shelf muds. Int J Syst Bacteriol 48, 965-972.

Venkateswaran, K., Moser, D. P., Dollhopf, M. E. \& 10 other authors (1999). Polyphasic taxonomy of the genus Shewanella and description of Shewanella oneidensis sp. nov. Int J Syst Bacteriol 49, 705-724.

Vogel, B. F., Jøgensen, K., Christensen, H., Olsen, J. E. \& Gram, L. (1997). Differentiation of Shewanella putrefaciens and Shewanella alga on the basis of whole-cell protein profiles, ribotyping, phenotypic characterization and 16S rRNA gene sequence analysis. Appl Environ Microbiol 63, 2189-2199.

Wayne, L. G., Brenner, D. J., Colwell, R. R. \& 9 other authors (1987). International Committee on Systematic Bacteriology. Report of the ad hoc committee on reconciliation of approaches to bacterial systematics. Int $J$ Syst Bacteriol 37, 463-464. 